\title{
Effect of Foliar Fungicide and Insecticide on Haill-Damaged Soybean
}

\begin{abstract}
Adam J. Sisson and Yuba R. Kandel, Department of Plant Pathology and Microbiology, Iowa State University, Ames 50011; Chad E. Hart, Department of Economics, Iowa State University, Ames 50011; Amy Asmus, Asmus Farm Supply, Rake, IA 50465; Stith N. Wiggs and Daren S. Mueller, Department of Plant Pathology and Microbiology, Iowa State University, Ames 50011
\end{abstract}

Accepted for publication 21 April 2016. Published 20 June 2016.

\section{ABSTRACT}

Sisson, A. J., Kandel, Y. R., Hart, C. E., Asmus, A., Wiggs, S. N., and Mueller, D. S. 2016. Effect of foliar fungicide and insecticide on hail-damaged soybean. Plant Health Prog. 17:141-148.

A fungicide (pyraclostrobin) and an insecticide (alpha-cypermethrin) were applied alone or in combination to hail-injured soybean to determine if yield could be preserved or foliar disease prevented. Pesticides were applied at approximately R3 growth stage and hail injury was simulated with an ice-propelling machine at approximately R1 and $\mathrm{R} 4$ growth stages over three years at three Iowa locations. Disease severity was low throughout the study, and included Septoria brown spot, downy mildew, and Cercospora leaf blight. Differences in disease severity among treatments receiving hail and those that did not receive hail were not consistently detected. More importantly, foliar disease severity did not differ among pesticide treatments and untreated controls. Simulated hail caused significant $(P=0.1)$ yield loss. No difference in yield was observed between untreated and pesticide-treated plots within hail events, except for two site years when hail damage occurred at R1. Seed moisture was generally higher in plots with R1 hail damage. Fungicide and insecticide applied in combination to hail-damaged soybean was more likely to result in a positive economic return than either applied alone. Based on results, R3 fungicide application to soybean injured by hail at R1 or R4 will likely provide little yield-preserving or disease-limiting benefits when foliar disease severity is low.

\section{INTRODUCTION}

Soybean (Glycine max) was planted on 9.9 million acres in Iowa in 2014, and was second only to corn planted in the state (USDA NASS). The value of soybean to the state was more than $\$ 5.1$ billion (USDA NASS). The number of soybean acres planted in the North Central region of the United States was nearly 67.5 million in 2014, which accounted for approximately $81 \%$ of total U.S. soybean acres (USDA NASS). In the past decade, fungicide application to these acres has increased for a variety of reasons including better grain prices, perceived disease risk, product development, and product marketing (Hershman et al. 2011; Mueller et al. 2013). Before 2004, foliar-applied fungicide in Iowa soybean was rare (Kyveryga et al. 2013); fungicide applications are now considered for plant health reasons even when disease is absent. Plant health benefits claimed include increased seed quality, seed size uniformity, increased nutrient use efficiency, increased photosynthetic efficiency, and better tolerance to crop stresses including drought, frost, ozone, and hail (BASF Corporation 2008a, 2008b, and 2009).

Crop injury due to hail may seem like an isolated phenomenon, occurring on only a few acres each year. However, in Iowa hail destroys approximately $4.5 \%$ of soybeans annually (NOAA 2006). This translates into 445,500 acres affected in Iowa alone in 2014 , worth an estimated $\$ 4.5$ million. Economic losses due to hail can be substantial. For example, over an 11-year period starting in 2001, U.S. soybean farmers experienced estimated

Corresponding author: Daren Mueller. Email: dsmuelle@iastate.edu.

doi:10.1094/PHP-RS-16-0012

(C) 2016 The American Phytopathological Society annual hail losses of almost \$100 million (Lee and Zarnstorff 2012). The National Crop Insurance Service paid out an annual average of nearly $\$ 54$ million for 2.3 million acres per year for hail claims on soybean from 2003 to approximately 2010 (Conley et al. 2010). Others estimate losses to be higher; for example, it is claimed that in Minnesota soybean alone, $\$ 60$ million is lost annually due to hail (Hicks and Naeve 2013).

When hail injures soybean, farmers and agronomists may consider applying fungicides as a way to mitigate the affects of hail injury. Another justification presented for an application is soybean tissue injury from hail provides an entry point for certain pathogens (C. McGrath, Iowa Soybean Research Center, personal communication). However, tissue wounding is not a requirement for infection by the fungal pathogens that are currently managed using foliar-applied fungicides, including frogeye leaf spot (Cercospora sojina) and Septoria brown spot (Septoria glycines) (Hartman et al. 2015). Diseases caused by bacteria, such as bacterial pustule (Xanthomonas axonopodis pv. glycines), are favored by plant tissue damage, but fungicides are not active against bacterial pathogens. Moreover, it is sometimes recommended that farmers add an insecticide when applying fungicide. There are numerous insect pests of soybean, such as soybean aphid (Aphis glycines) and bean leaf beetle (Cerotoma trifurcata), that occasionally warrant management using a foliarapplied insecticide (Hodgson et al. 2012).

In the limited number of replicated studies on hail-damaged soybean, no significant yield responses were observed from a variety of fungicide or fungicide with insecticide applications after hail injury to mostly reproductive-stage soybean (Arneson and Giesler 2014a, 2014b; Conley et al. 2010; Licht and Barnet 2009; D. Smith, personal communication). However, to adequately test the effect of a fungicide on hail-damaged soybean, 
TABLE 1

Cultivar, population, plot length, planting date, and harvest date for individual site years for a field study planted in 30 -inch row spacing to evaluate the interaction of pesticides and hail on soybean.

\begin{tabular}{lllccc} 
Location & Year & Cultivar & $\begin{array}{c}\text { Population } \\
\text { (seeds planted/acre) }\end{array}$ & $\begin{array}{c}\text { Plot length } \\
\text { (approx. ft) }\end{array}$ & Planting date \\
\hline Ames & 2012 & Asgrow 2431 & 128,000 & 17.5 & 11-May \\
Rake & 2012 & Pioneer 92Y22 & 165,000 & 17.6 & 12-May \\
Ames & 2013 & Asgrow A2534 & 152,000 & 18.0 & 3-Jun \\
Rake & 2013 & Channel 2305 & 165,000 & 17.5 & $24-$-Oay \\
Ames & 2014 & Pioneer 92Y53 & 140,000 & 17.5 & 19-Oct \\
Kanawha & 2014 & Pioneer P22T69R & 2-Oct \\
\hline
\end{tabular}

${ }^{\mathrm{x}}$ At maturity, some rows were visibly lighter than other rows indicating two varieties were planted by mistake, the second of which is unknown. This was controlled for by replication.

a control that does not receive hail at the same site as the damaged crop is required. Because of this, it is necessary to test the effect of fungicide and insecticide on hail-damaged soybean compared to soybean that did not receive hail in the same study.

The goal of this research was to determine if there is a benefit to hail-damaged soybean from a foliar-applied fungicide and/or insecticide. Therefore, the objectives in this study were to: (i) examine the effect of hail damage at reproductive growth stages R1 and R4 (Pedersen 2009) on foliar disease, seed moisture, and yield; and (ii) determine if foliar-applied fungicide, fungicide with insecticide, or insecticide at R3, after simulated hail at R1 and before simulated hail at $\mathrm{R} 4$, prevented foliar disease development or preserved yield. In addition to comparing yield and disease severity, we also considered the profitability of pesticide use on hail-damaged soybean.

\section{FIELD EXPERIMENTS}

Experimental plots were established at Asmus Farm Supply near Rake, IA, in 2012 and 2013; the Iowa State University (ISU) Agricultural Engineering and Agronomy Farm near Ames, IA, in 2012, 2013, and 2014; and the ISU Northern Research Farm in Kanawha, IA, in 2014, for a total of six site years. At each location, the experimental design was a $3 \times 4$ factorial randomized complete block with four replications. Soybean plots consisted of four rows of soybean (30-inch spacing) at least 17.5 feet long. Disease and yield data were obtained from the middle two rows. Plots were organized in multiple rows across a field with a drive row on at least one side of the plots to allow for movement of machinery. Plots within a row were separated by at least 2 feet from other plots by mechanically removing plants or by not seeding this area during planting. Cultivar, population, plot length, planting date, and harvest date varied by site year (Table 1).
This study consisted of 12 treatments (Table 2). The simulatedhail treatments were applied at or near R1 and R4 soybean growth stages each year (Table 3) using a custom-built, PTO-powered ice applicator (see a demonstration at http://www.news.iastate.edu /video/view/id/cwhtyeuijok). The PTO-powered applicator had the ability to simulate hail injury by propelling ice cubes (commonly available from grocery or convenience stores in bags 20 lbs. or less) from above and to the side of plants fast enough to cause more realistic impacts to leaves, stems, petioles, pods, and other tissue (Fig. 1). Within each field plot, a standard of plant injury due to hail application was based on visual reference by the applicator during the ice-application process. A non-hail

\begin{tabular}{ll} 
TABLE 2 \\
\multicolumn{2}{c}{ Summary of treatments from a three-year field study to } \\
evaluate the interaction of pesticides and hail on soybean. \\
Hail application factor & Fungicide/insecticide application factor \\
\hline None & None \\
None & Fungicide \\
None & Fungicide + insecticide \\
None & Insecticide \\
R1y & None \\
R1 & Fungicide \\
R1 & Fungicide + insecticide \\
R1 & Insecticide \\
R4 & None \\
R4 & Fungicide \\
R4 & Fungicide + insecticide \\
R4 & Insecticide \\
\hline
\end{tabular}

${ }^{\mathrm{x}}$ Fungicide and insecticide treatments were applied at R3.

y Soybean growth stage R1, or "beginning bloom."

z Soybean growth stage R4, or "full pod."

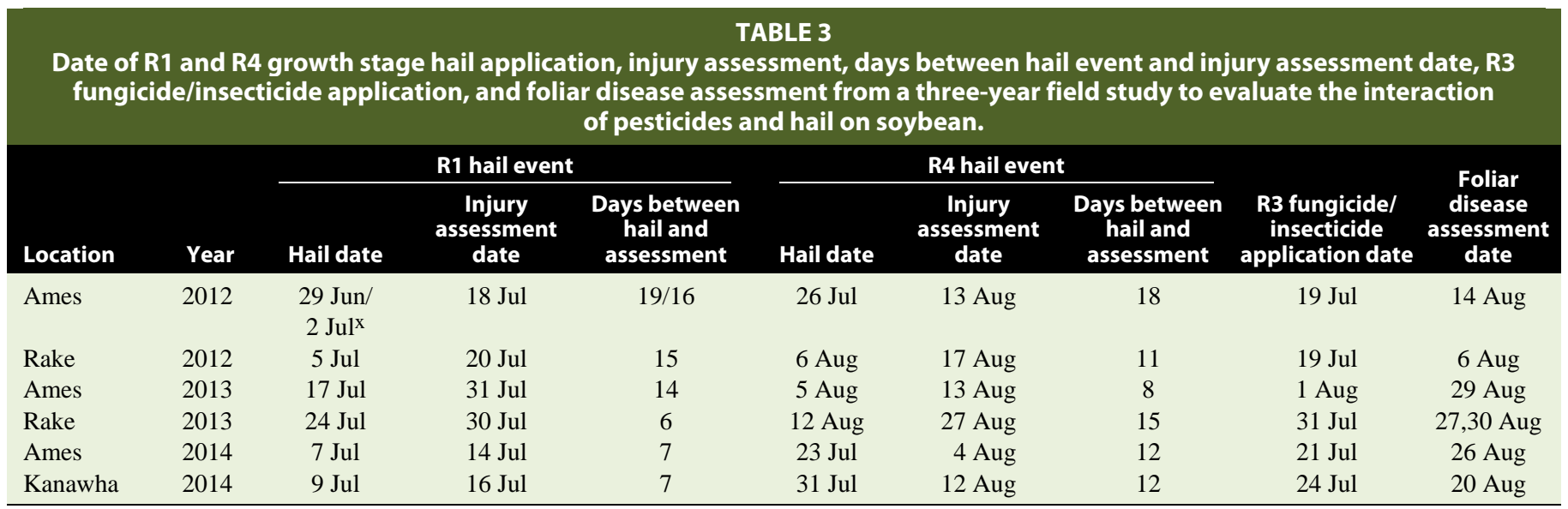

$\mathrm{x}$ The R1 hail application at Ames 2012 was started on June 29 but had to be delayed until July 2 due to hot weather. 
treatment was included in the study as a control. The middle two rows of each four-row plot received simulated hail. The outer two rows of the plot were damaged using weed trimmers to minimize the affect of otherwise healthy plants on data rows.

The pesticide treatments were applications of the fungicide Headline (pyraclostrobin; BASF Corporation, Florham Park, NJ; $6 \mathrm{fl} \mathrm{oz/acre);} \mathrm{a} \mathrm{combination} \mathrm{of} \mathrm{Headline} \mathrm{and} \mathrm{the} \mathrm{commercial}$ insecticide Fastac (alpha-cypermethrin; BASF Corporation; $3.2 \mathrm{fl}$ oz/acre); and Fastac. A non-ionic surfactant at $0.25 \%$ v/v was included with treatments containing Fastac at all locations except Rake in 2012 and 2013, where $0.125 \%$ v/v of a non-ionic surfactant was included with all treatments. Treatments were applied using a self-propelled, custom-built plot sprayer using \#1.5 XR TeeJet $110^{\circ} 015 \mathrm{VS}$ (TeeJet Technologies, Wheaton, IL) on 20-inch centers at 35 psi from a $\mathrm{CO}_{2}$ tank (Ames 2013; Ames 2014; Kanawha 2014); a backpack spray applicator (Ames 2012; Rake 2013), or a pull-behind plot sprayer with cone inductors (Rake 2012) at approximately 15 to 20 gal/acre water volume. In general, sprays were made using flat-fan nozzles with mediumsized droplets at approximately 35 psi. Pesticide application occurred approximately at soybean growth stage R3 (Table 3). There was an untreated treatment at all locations for a control.

\section{DATA COLLECTION}

Simulated hail injury to plants was assessed after each hail event (Table 3). Three arbitrarily chosen plots receiving the R1 and R4 hail treatments were assessed for hail injury by determining: (i) percent stand reduction by counting the number of dead plants out of 100; (ii) percent missing nodes by subtracting the remaining nodes on a plant from the number of nodes at the hail event; and (iii) percent defoliation due to hail. Percent pod loss was also estimated for R4 hail treatments by comparing the number of pods left on hailed plants to nearby nonhailed plants. An estimated yield loss based on observed damage was compared to actual yield loss.

Foliar disease assessment occurred after the R4 hail event (Table 3). Foliar fungal disease severity was visually estimated for 10 leaflets in the lower canopy (five from each of the two data rows) and 10 leaflets in the upper canopy (five from each of the two data rows) ( $n=20$ leaves) each site year except Rake 2012, where only the lower canopy was assessed. This was because there was no noticeable disease in the upper canopy at Rake in 2012. Other diseases and concerns were noted to identify possible yield-limiting issues. Data on insect injury or presence was not collected during this study.

At maturity, plots at Ames in 2012-2014, Kanawha in 2014, and Rake in 2013 were harvested using a 2009 SPC20 Almaco specialized plot combine with a proprietary weight system (ALMACO, Nevada, IA). Plots at Rake in 2012 were harvested with a plot combine and grain weight was determined using a weigh wagon (unknown make and model); moisture was determined post harvest using a GAC2100 (DICKEY-john Corporation, Auburn, IL). Harvest weight was adjusted to $13 \%$ moisture content and yield was converted to bushels per acre.

\section{ECONOMIC METHODS}

To examine the economic costs and benefits of the pesticide applications, the data for each plot was evaluated assuming the

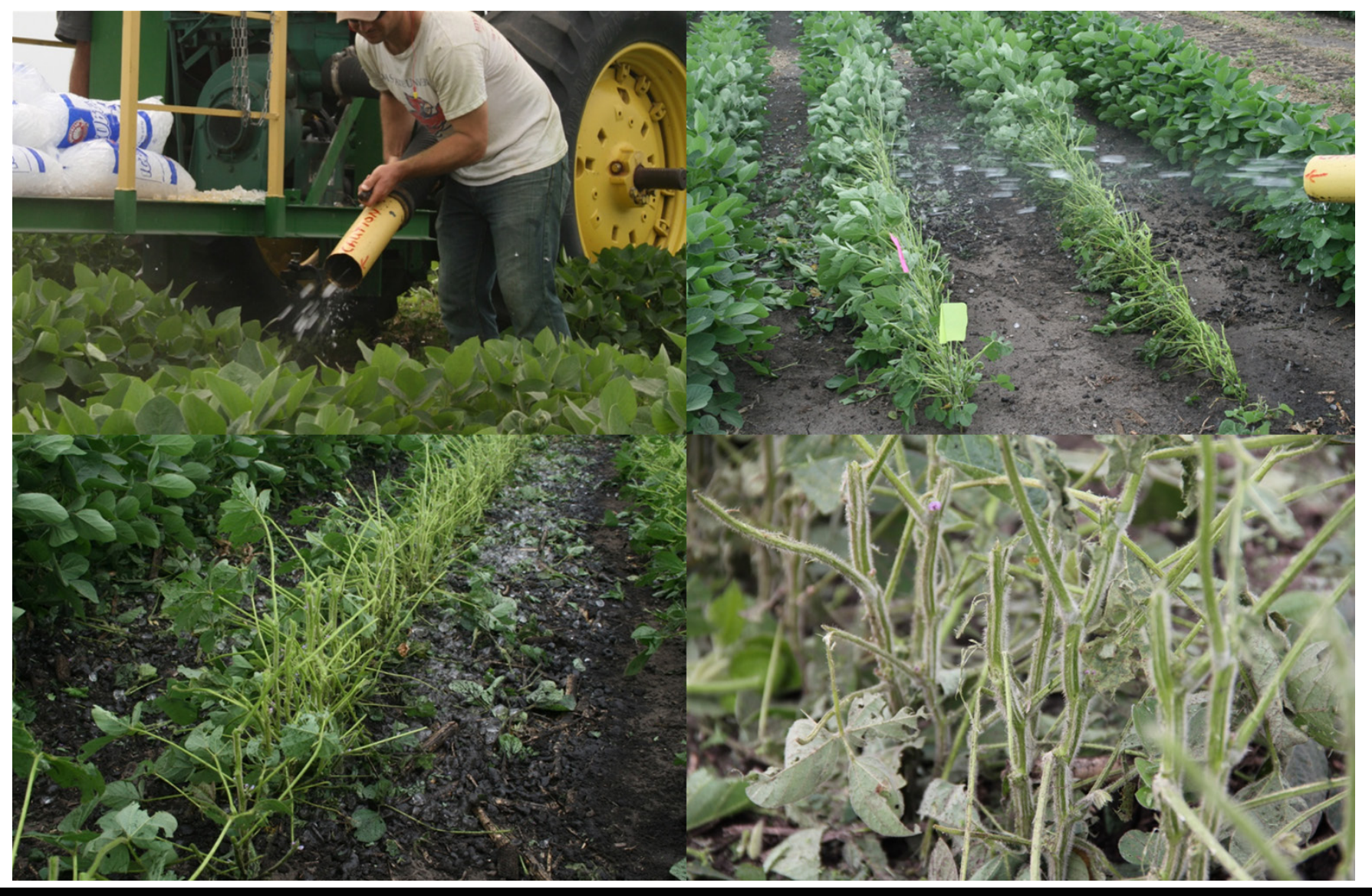

FIGURE 1

Simulation of hail to soybean and subsequent injury to plant tissue. 
following price and costs. The soybean price was set at $\$ 9.54 / \mathrm{bu}$, the price reported by USDA-AMS in their "Interior Iowa Daily Grain Prices" report on 6 August 2015. Cost for the pesticides in the application were based on values of $\$ 372 /$ gal for Headline, \$117/gal for Fastac, and \$24/gal for NIS. The cost of application was taken from the 2015 Iowa Farm Custom Rate Survey for selfpropelled ground spraying, \$7.70/gal (Plastina et al. 2015). The financial benefit of the application (product of the soybean price and the yield difference between the treatment and the control) was compared to the financial costs of the application (sum of the pesticides and application costs). The average economic return of the treatments were calculated, along with the probability of a positive economic return.

\section{STATISTICAL ANALYSIS}

ANOVA was performed using PROC GLIMMIX in SAS version 9.3 (SAS Institute Inc., Cary, NC). Fixed effect factors were treatments (hail and pesticide) and replication was a random effect factor. ANOVA was performed individually for each site year. Pesticide treatments were examined within each site year and also within hail events where pesticide was used as a fixed factor and replication was a random factor. Means were compared using protected Fisher's LSD at $P=0.10$.

\section{EFFECT OF HAIL ON PLANT TISSUE}

A natural hail event occurred at two of the six site years in this study, Ames 2013 and Kanawha 2014. Hail occurred during an early reproductive growth stage (R1-R2) the week of 22 July in Ames 2013 and caused minimal defoliation (9.6\%), node loss (2.5\%), and stand loss (1.3\%), and thus less than $1 \%$ estimated yield loss (Klein and Shapiro 2011). At Kanawha 2014, hail occurred on 16 June at approximately V2, resulting in about $35 \%$ defoliation; however this amount of defoliation at this growth stage should not impact final yield (Klein and Shapiro 2011).

Estimated injury caused by simulated hail treatments varied by location, year, and growth stage and was due to stand loss, defoliation, node loss, and pod loss (Table 4). Overall, estimated injury across site years was $10 \%$ and $40.9 \%$ at R1 and R4, respectively, while actual average yield loss due to simulated hail was $26.9 \%$ at $\mathrm{R} 1$ and $27.4 \%$ at R4. Stem bruising also was observed but was not quantified.

\section{EFFECT OF SIMULATED HAIL ON LEAF DISEASE, YIELD, AND MOISTURE}

Simulated hail injury caused significant $(P=0.1)$ yield loss at $\mathrm{R} 1$ and R4 each site year compared to non-hail controls (Table 5). On average, R1 hail decreased yield by 15.4 bu/acre and R4 hail decreased yield by 15.9 bu/acre. In three of six site years, hail at R1 decreased yield the most while hail at R4 decreased yield the most at the other three site years.

Percent moisture in harvested soybeans was nearly always higher in plots receiving $\mathrm{R} 1$ hail than in plots with hail at R4 or that did not receive hail, averaging $2.2 \%$ and $2.1 \%$ more than non-hail and R4 hailed plots, respectively (Table 5).

Septoria brown spot was very common in the lower canopy. In the upper canopy, downy mildew (Peronospora manshurica) was the most commonly observed foliar disease at Ames 2013, Ames 2014, and Kanawha 2014. Septoria brown spot and frogeye leaf spot were sometimes present in the upper canopy at very low, non-yield limiting levels. Cercospora leaf blight (Cercospora spp.) was present at multiple locations in the upper canopy; at Rake 2013, it was the primary fungal disease, occurring at higher severity in plots receiving R1 hail than non-hailed plots or plots with R4 hail. In general, non-fungal foliar diseases such as soybean vein necrosis (Soybean vein necrosis virus) and bacterial blight (Psuedomonas savastanoi pv. glycinea) were removed from the main disease analysis because foliar fungicides are not labeled to manage these diseases. When these non-fungal diseases could be analyzed separately, differences in severity were sometimes observed between hail treatments, but disease severity was always very low. Foliar fungal disease severity was low throughout the study, averaging $0.9 \%$ on lower canopy leaves and $0.9 \%$ in the upper canopy (Table 5). Although there was not enough disease to draw any conclusions, hail did not generally increase disease risk.

\begin{tabular}{|c|c|c|c|c|c|c|c|c|}
\hline \multirow[b]{2}{*}{ Year } & \multirow[b]{2}{*}{ Location } & \multirow{2}{*}{$\begin{array}{c}\text { Growth } \\
\text { stage }\end{array}$} & $\begin{array}{l}\text { de loss, po } \\
\text { ompared t } \\
\text { tudy to ev }\end{array}$ & $\begin{array}{l}\text { TA } \\
\text { sss, and co } \\
\text { iree non-h } \\
\text { ate the int }\end{array}$ & $\begin{array}{l}4 \\
\text { sponding e } \\
\text { treatment } \\
\text { ction of pes }\end{array}$ & $\begin{array}{l}\text { ated yield } \\
\text { for each s } \\
\text { les and ha }\end{array}$ & $\begin{array}{l}\text { and actual yiel } \\
\text { jear and hail ev } \\
\text { soybean. }\end{array}$ & $\begin{array}{l}\text { ss percent } \\
\text { from a }\end{array}$ \\
\hline & & & Stand loss & Node loss & Defoliation & Pod lossu & $\begin{array}{l}\text { Total estimated } \\
\text { yield loss }(\%)^{\mathbf{v}}\end{array}$ & $\begin{array}{l}\text { Actual yield } \\
\text { loss }(\%)^{\mathrm{w}}\end{array}$ \\
\hline 2012 & Ames & $\mathrm{R} 1^{\mathrm{x}}$ & 1.0 & 26.5 & 92.3 & - & 14.0 & 26.5 \\
\hline 2013 & Rake & $\mathrm{R} 1$ & 4.0 & 9.6 & 38.5 & - & 5.0 & 33.1 \\
\hline 2014 & Ames & $\mathrm{R} 1$ & 0.0 & 10.3 & 55.8 & - & 10.0 & 16.3 \\
\hline 2014 & Kanawha & $\mathrm{R} 1$ & 0.7 & 10.4 & 48.3 & - & 5.0 & 25.4 \\
\hline 2012 & Ames & $\mathrm{R} 4 \mathrm{y}$ & ${ }_{-\mathrm{z}}$ & ${ }^{\mathrm{z}}$ & 26.0 & 33.1 & 39.1 & 16.6 \\
\hline 2012 & Rake & $\mathrm{R} 4$ & $-\mathrm{z}$ & ${ }_{-z}$ & 41.8 & 29.7 & 38.7 & 16.6 \\
\hline 2013 & Ames & $\mathrm{R} 4$ & 0.7 & 3.8 & 34.2 & 17.5 & 28.5 & 24.5 \\
\hline
\end{tabular}

u Percent pod loss associated directly to percent yield loss for the purpose of this comparison.

${ }^{\mathrm{v}}$ Total estimated yield loss percent obtained by determining corresponding yield loss for each damage parameter (Klein and Shapiro 2011).

${ }^{\mathrm{w}}$ Actual yield loss compared to non-hail plots.

x Soybean growth stage R1, or "beginning bloom."

y Soybean growth stage R4, or "full pod."

${ }^{\mathrm{z}}$ Missing data. The average estimated yield loss for these factors during 2013 and 2014 was $6.5 \%$. 


\section{FOLIAR FUNGICIDE/INSECTICIDE EFFECT ON LEAF}

\section{DISEASE, YIELD, AND MOISTURE}

Fungicide alone, fungicide in combination with insecticide, and insecticide alone had no statistically significant impact on soybean yield in non-hail plots and R4 hail plots $(P=0.1$; Table $6)$. When there was a difference observed for treatments within the R1 hail event (Rake 2012 and Ames 2014), no discernable pattern emerges as Rake 2012 data stands nearly in opposition to that of Ames 2014.
Percent moisture among pesticide treatments was not significant at any site year in non-hail and R1 hail plots (data not shown). In R4 hail plots, it was only Ames 2014 where untreated control plots had significantly more moisture $(21.8 \%)$ than pesticide-treated plots (averaging 15.6\%).

Treatment effects were not detected for the few differences in fungal foliar disease severity that were observed in upper and lower canopy among pesticide treatments and untreated controls at all locations (Tables 7 and 8).

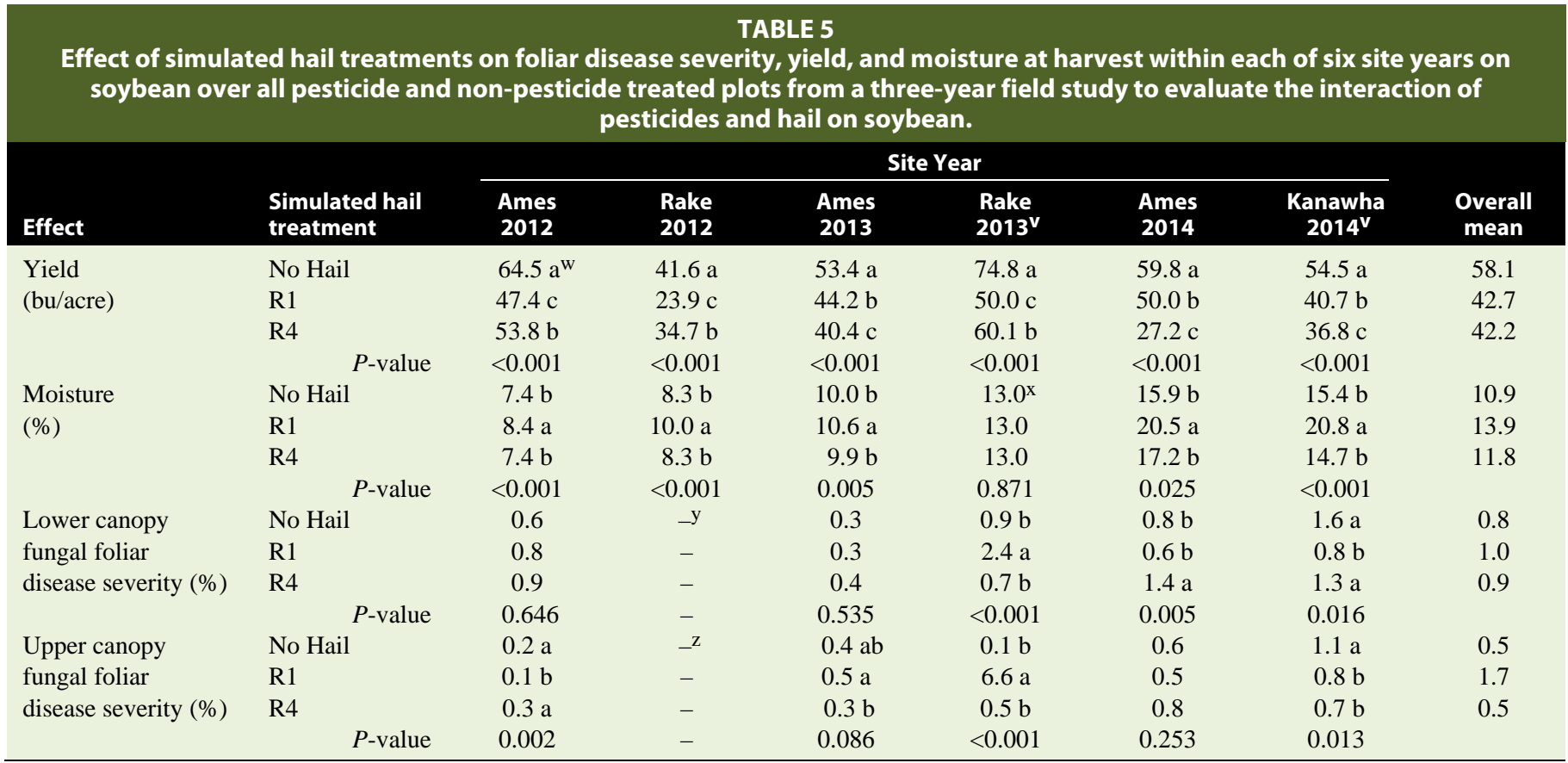

${ }^{\mathrm{v}}$ These locations received natural hail across the experimental plot.

${ }^{\mathrm{w}}$ Means followed by the same letter are not significantly different $(P=0.1)$.

${ }^{\mathrm{x}}$ Means not followed by letters designates no significant difference $(P=0.1)$ among that particular group of means.

${ }^{\mathrm{y}}$ Data discarded due to collection error.

${ }^{\mathrm{z}}$ Data not recorded due to lack of disease at site year.

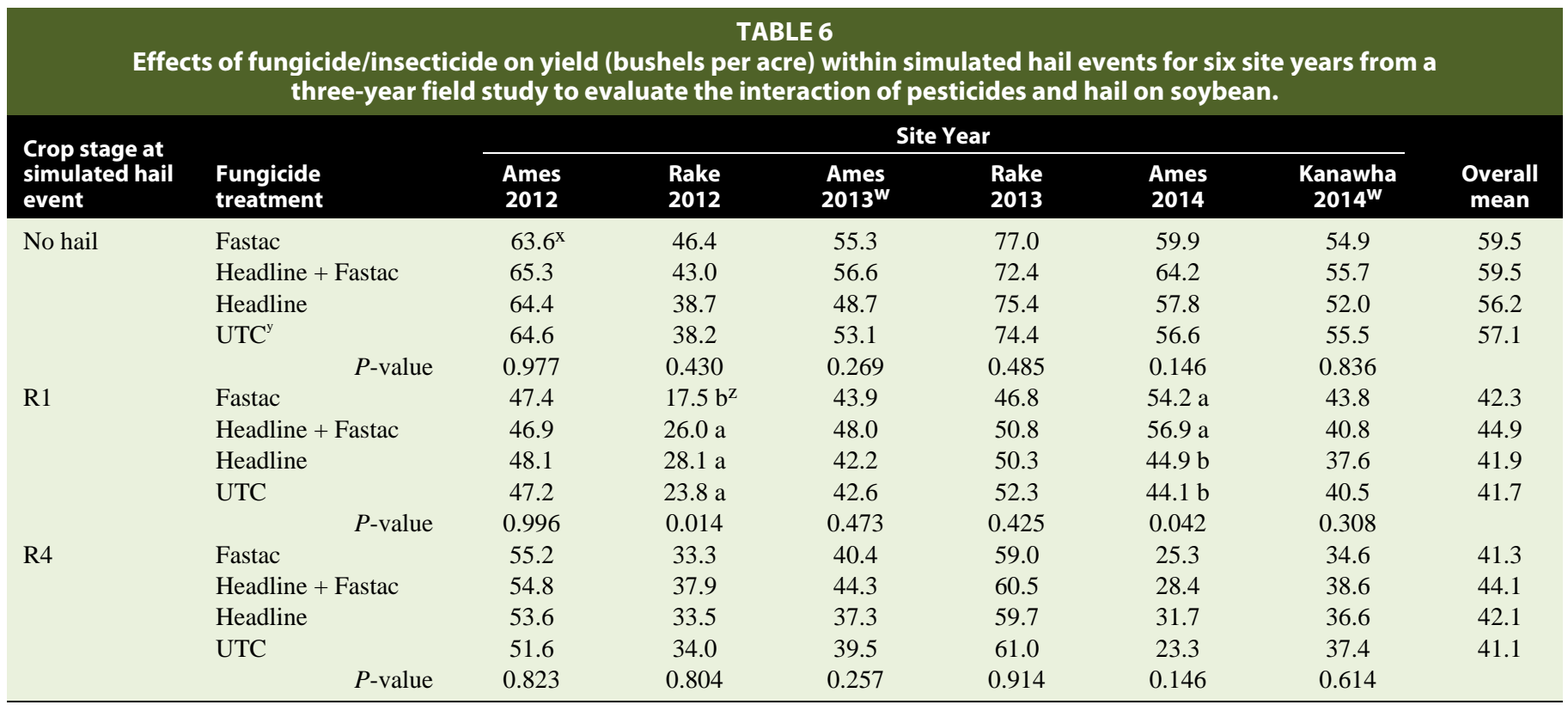

${ }^{\mathrm{w}}$ These locations received natural hail across the experimental plot.

${ }^{x}$ Means not followed by letters designates no significant difference $(P=0.1)$ among that particular group of means.

$\mathrm{y}$ UTC $=$ untreated control.

${ }^{\mathrm{z}}$ Means followed by the same letter are not significantly different $(P=0.1)$. 


\section{PROBABILITY OF POSITIVE ECONOMIC RESPONSE TO} FUNGICIDE AND/OR INSECTICIDE APPLICATIONS

Based on the price and costs of the pesticides and applications outlined earlier, the economic return for each application was evaluated. Overall, combining the results from the pesticide applications regardless of hail damage, the pesticide applications provided a return of $-\$ 8.77$ per acre (Table 9$)$. Forty-five percent of the applications provided a positive economic return. In comparing the economic returns, the pesticide return in the hail scenarios is roughly on par with the returns with no hail damage
( $-\$ 8.84$ per acre for the hail scenarios versus $-\$ 8.64$ per acre otherwise). The percentage of positive returns was slightly higher in the non-hail plots. However, there were sizable differences between the returns for the various pesticide applications. For the fungicide only treatment, returns were negative regardless of hail and the probability of a positive economic return was approximately one-third or below. For the insecticide and NIS treatment, there was a split in returns. For the plots without hail damage, this treatment did achieve an average positive return of $\$ 13.02$ per acre, with more than half of the plots having a positive

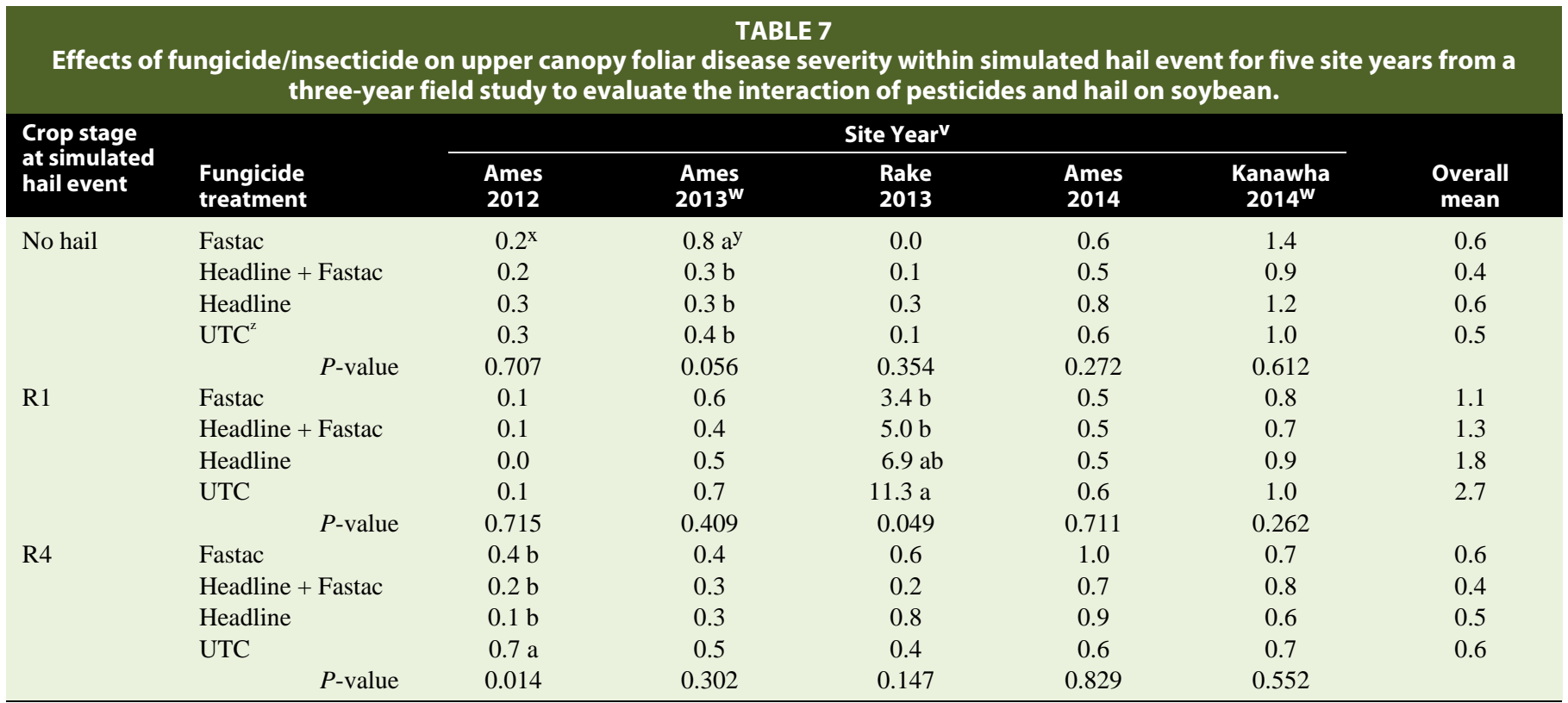

${ }^{\mathrm{v}}$ Data from Rake 2012 was not collected as there was no noticeable disease in the upper canopy.

${ }^{\mathrm{w}}$ These locations received natural hail across the experimental plot.

${ }^{\mathrm{x}}$ Means not followed by letters designates no significant difference $(P=0.1)$ among that particular group of means.

y Means followed by the same letter are not significantly different $(P=0.1)$.

z UTC $=$ untreated control.

\begin{tabular}{|c|c|c|c|c|c|c|c|c|}
\hline \multirow{3}{*}{$\begin{array}{l}\text { Crop stage at } \\
\text { simulated hail } \\
\text { event }\end{array}$} & \multirow[b]{3}{*}{$\begin{array}{l}\text { Fungicide } \\
\text { treatment }\end{array}$} & $\begin{array}{l}\text { ver ca } \\
\text { udy t }\end{array}$ & $\begin{array}{l}\text { iar c } \\
\text { te th }\end{array}$ & $\begin{array}{l}8 \\
\text { everit } \\
\text { ction }\end{array}$ & $\begin{array}{l}\text { simul } \\
\text { ides a }\end{array}$ & $\begin{array}{l}\text { il even } \\
\text { on soyk }\end{array}$ & ix site ye & om a \\
\hline & & \multicolumn{6}{|c|}{ Site Year } & \multirow[b]{2}{*}{$\begin{array}{c}\text { Overall } \\
\text { mean }\end{array}$} \\
\hline & & $\begin{array}{l}\text { Ames } \\
2012\end{array}$ & $\begin{array}{l}\text { Rake } \\
2012\end{array}$ & $\begin{array}{l}\text { Ames } \\
2013^{V}\end{array}$ & $\begin{array}{l}\text { Rake } \\
2013\end{array}$ & $\begin{array}{l}\text { Ames } \\
2014\end{array}$ & $\begin{array}{c}\text { Kanawha } \\
2014^{v}\end{array}$ & \\
\hline \multirow[t]{5}{*}{ No hail } & Fastac & $0.8^{\mathrm{w}}$ & 0.8 & 0.4 & 0.7 & 0.6 & 1.9 & 0.9 \\
\hline & Headline + Fastac & 0.4 & 0.7 & 0.2 & 1.0 & 0.5 & 1.6 & 0.7 \\
\hline & Headline & 0.5 & 0.7 & 0.3 & 0.7 & 1.3 & 1.3 & 0.8 \\
\hline & $\mathrm{UTC}^{\mathrm{x}}$ & 0.9 & 1.2 & 0.3 & 1.2 & 0.6 & 1.6 & 0.9 \\
\hline & $P$-value & 0.180 & 0.293 & 0.487 & 0.411 & 0.617 & 0.826 & \\
\hline \multirow[t]{4}{*}{$\mathrm{R} 1$} & Fastac & 0.3 & 0.3 & 0.4 & 1.9 & $0.95 \mathrm{a}^{\mathrm{y}}$ & 0.7 & 0.8 \\
\hline & Headline + Fastac & 0.6 & 0.1 & 0.4 & 2.2 & $0.33 \mathrm{bc}$ & 1.0 & 0.8 \\
\hline & Headline & 0.3 & 0.1 & 0.4 & 3.2 & $0.28 \mathrm{c}$ & 0.8 & 0.8 \\
\hline & UTC & 1.8 & 0.1 & 0.1 & 2.3 & $0.70 \mathrm{ab}$ & 1.0 & 1.0 \\
\hline \multirow{2}{*}{$\mathrm{R} 4$} & UTC & 0.6 & - & 0.5 & 0.6 & $2.0 \mathrm{a}$ & $1.7 \mathrm{a}$ & 1.1 \\
\hline & $P$-value & 0.312 & - & 0.359 & 0.783 & 0.092 & 0.061 & \\
\hline
\end{tabular}

${ }^{\mathrm{v}}$ These locations received natural hail across the experimental plot.

${ }^{\mathrm{w}}$ Means not followed by letters designates no significant difference $(P=0.1)$ among that particular group of means.

$\mathrm{x}$ UTC $=$ untreated control.

y Means followed by the same letter are not significantly different $(P=0.1)$.

${ }^{\mathrm{z}}$ Data discarded due to collection error. 
return. For the hail-damage plots, the average per-acre return was negative, with less than half of the plots having a positive return. Combining the fungicide, insecticide, and NIS treatments reduced the variability of economic returns and, in most cases, increased the chance of the treatment providing a positive economic return.

Examining the hail events more specifically, the timing of the hail event did influence the economic return. With hail damage at the R1 stage, the average returns were negative for the fungicide treatment and for the insecticide and NIS treatment, while the combination treatment resulted in a positive return (Table 10). Only the combination treatment had more than a 50\% likelihood of a positive economic return. With hail damage at the R4 stage, the economic returns had a similar pattern.

\section{CONCLUSIONS AND IMPLICATIONS FOR MANAGEMENT}

Results of this study indicate that R1 hail injury in soybean should not be, by itself, a reason to apply pyraclostrobin at R3 for yield preservation or disease management in years with low disease risk. During this study, fungicide was not beneficial, and hail injury at R1 and R4 did not increase disease risk consistently.

\begin{tabular}{|c|c|c|c|}
\hline \multicolumn{4}{|c|}{$\begin{array}{l}\text { TABLE } 9 \\
\text { Summary economic data for fungicide and insecticide } \\
\text { applications from a three-year field study to evaluate } \\
\text { the interaction of pesticides and hail on soybean. }\end{array}$} \\
\hline & Fungicide & $\begin{array}{c}\text { Insecticide + } \\
\text { NIS }\end{array}$ & $\begin{array}{c}\text { Fungicide }+ \\
\text { Insecticide }+ \\
\text { NIS Combination }\end{array}$ \\
\hline \multicolumn{4}{|l|}{ Overall } \\
\hline Average Return & $(\$ 24.64)^{\mathrm{x}}$ & $(\$ 0.76)$ & $(\$ 0.81)$ \\
\hline$\%$ above $\$ 0^{y}$ & $32 \%$ & $46 \%$ & $56 \%$ \\
\hline \multicolumn{4}{|l|}{ With Hail Damage } \\
\hline Average Return & $(\$ 20.20)$ & $(\$ 7.37)$ & $\$ 1.05$ \\
\hline$\%$ above $\$ 0$ & $35 \%$ & $40 \%$ & $56 \%$ \\
\hline \multicolumn{4}{|l|}{ Without Hail Damage } \\
\hline Average Return & $(\$ 33.54)$ & $\$ 13.02$ & $(\$ 4.52)$ \\
\hline$\%$ above $\$ 0$ & $25 \%$ & $61 \%$ & $54 \%$ \\
\hline
\end{tabular}

${ }^{\mathrm{x}}$ Parenthesis denote a negative value.

y Percentage of plots with a positive economic return. Economic return was calculated by subtracting the costs of the treatment (sum of the pesticides and application costs) from the benefit (product of the soybean price and the yield difference between the treatment and the control).

\begin{tabular}{|c|c|c|c|}
\hline \multicolumn{4}{|c|}{$\begin{array}{l}\text { Table } 10 \\
\text { Economic data for fungicide and insecticide applications by } \\
\text { hail event from a three-year field study to evaluate the } \\
\text { interaction of pesticides and hail on soybean. }\end{array}$} \\
\hline & Fungicide & $\begin{array}{c}\text { Insecticide + } \\
\text { NIS }\end{array}$ & $\begin{array}{l}\text { Fungicide + } \\
\text { Insecticide + } \\
\text { NIS } \\
\text { Combination }\end{array}$ \\
\hline \multicolumn{4}{|l|}{ Hail at R1 } \\
\hline Average Return & $(\$ 23.97)^{\mathrm{x}}$ & $(\$ 5.75)$ & $\$ 2.08$ \\
\hline$\%$ above $\$ 0^{y}$ & $29 \%$ & $42 \%$ & $58 \%$ \\
\hline \multicolumn{4}{|l|}{ Hail at R4 } \\
\hline Average Return & $(\$ 16.42)$ & $(\$ 8.98)$ & $\$ 0.03$ \\
\hline$\%$ above $\$ 0$ & $42 \%$ & $38 \%$ & $54 \%$ \\
\hline
\end{tabular}

${ }^{x}$ Parenthesis denote a negative value.

y Percentage of plots with a positive economic return. Economic return was calculated by subtracting the costs of the treatment (sum of the pesticides and application costs) from the benefit (product of the soybean price and the yield difference between the treatment and the control).
Several previous studies have suggested limited benefits of pyraclostrobin fungicide use in soybean when disease risk is low (Bluck et al. 2015; Mahoney et al. 2015; Nelson et al. 2016; Swoboda and Pederson 2009). In similar research with simulated hail injury to corn, plants that were injured by hail had less disease than non-hailed corn (Sisson et al. 2016). Mahoney and Gillard (2014) also did not observe increased disease due to simulated hail in dry bean plots. However, research from Illinois on corn with simulated hail injury showed an increase in the fungal disease gray leaf spot (Cercospora zeae-maydis) in hailed corn in one year of a two-year study (Bradley and Ames 2010). Our results agree with previous assertions that fungicide should be a response to factors that increase risk of disease, including variety susceptibility, disease history, and weather favorable for disease development (Hershman et al. 2011); or from other parameters such as spring rainfall amounts (Kyveryga et al. 2013). Furthermore, Bluck et al. (2015) found soybean yield response to pyraclostrobin was more likely to occur when soybean yields were above average ( $>52$ bu/acre). Because hail injury may reduce yield potential, fungicide use on hail injured soybean may be less likely to result in soybean yield response than on non-hail injured soybean.

The economic results mostly follow the yield results. The estimation of the returns show that the combination of pyraclostrobin and alpha-cypermethrin increase the likelihood of a positive return in hail injured soybean compared to either product applied alone. Using the combination treatment, $58 \%$ of the plots resulted in a positive economic return for soybean with hail injury at R1. However, the average return was low (\$2.08), so careful consideration must be given to the risks involved when choosing to apply these pesticides after hail injury as substantial risk of a negative return exists. The results presented here are based on specific values for soybean price and chemical and application costs. To account for variability in these values, a calculator was created that allows users to input their own price/cost data to help estimate response in a particular soybean field using the yield data from this study. The calculator can be accessed at http://www.ipm.iastate.edu/soybeancalculator.

When R1 hail resulted in more yield loss than R4 hail, R1 hailed plots averaged $76 \%$ defoliation while $\mathrm{R} 4$ hailed plots averaged $33 \%$. Other injury parameters were also higher in R1 plots. Yield loss due to hail was always underestimated at R1 and overestimated at R4, by an average of $17 \%$ and $13 \%$, respectively. The differences in estimated yield loss and actual yield loss suggest either human error in damage estimations or that something more than severity of injury at a specific growth stage determines yield loss as a result of that injury. Rainfall amounts by county within a week of the hail event (day $1=$ hail day) may help explain results at five out of six site years as the least damaging hail event always had more precipitation within this timeframe compared to the most damaging hail event at every location except Rake 2013.

Grain moisture in R1 hailed plots was almost always higher compared to plots with either R4 hail or no hail. This value was more than 2 percentage points difference. This may be because plants receiving hail at $\mathrm{R} 1$ have the ability to initiate new flowers. However, plants injured at R4 have a limited ability to produce new flowers, and additional pod set would be limited. Senescence in plants hailed at R4 might even occur earlier (M. Licht, personal communication; Pederson 2009).

Production practices (e.g., tillage), weather (e.g., humidity), cultivar resistance, and other factors influence disease, and multiple factors may also affect fungicide and insecticide efficacy. The authors of this manuscript acknowledge the limited scope of 
this study and that different conditions may exist which could produce varying results from the ones observed here. Future inquiries are necessary to determine response of hail injured soybean during vegetative growth stages or if fungicide application in closer proximately to a hail event may provide yield or disease management benefits.

The information from this study will help farmers and agronomists to make more informed decisions about how fungicide and/or insecticide application at R3 affects soybean with hail injury. In short, there are little yield or disease management benefits in an R3 application of pyraclostrobin and/or alpha-cypermethrin to soybean injured by hail at R1 and $\mathrm{R} 4$ during years when disease risk is low. This could reduce unjustified pesticide applications and save farmers money during an already difficult crop loss situation.

\section{ACKNOWLEDGMENTS}

Special thanks to the United States Department of Agriculture (USDA) National Institute of Food and Agriculture (NIFA) for funding this research through the Regional Integrated Pest Management Competitive Grants Program-North Central Region (NC-RIPM) Project No. IOWN176014; and to Asmus Farm Supply in Rake, IA, for additional project funding. With much appreciation to Josh Dunn, Brandon Kleinke, Stuart McCulloh, Warren Pierson, Matthew Schnabel, Kent Sisson, and Micah Smidt for assisting with plot establishment, maintenance, data collection/handling, and keeping the hail machine from making slushies; the employees of Asmus Farm Supply for their time and efforts in planting, maintaining, and harvesting plots in Rake, IA. Thank you to Alison Robertson for critical review of this manuscript. A special thanks to several grocery store managers (especially Gary Gray at Hy-Vee in Ames) who supplied hundreds of bags of ice to fuel the hail machine!

\section{LITERATURE CITED}

Arneson, N. J., and Gielser, L. J. 2014a. Effects of foliar fungicides and fungicide-insecticide combinations on hail damaged soybean, 2013. Plant Dis. Manage. Rep. 8:FC182. doi:10.1094/PDMR08.

Arneson, N. J., and Gielser, L. J. 2014b. Effects of foliar fungicides on hail damaged soybean, 2013. Plant Dis. Manage. Rep. 8:FC181. doi:10.1094/PDMR08.

BASF Corporation. 2008a. Headline Fungicide. Label NVA 2008-04-0880327. Research Triangle Park, NC.

BASF Corporation. 2008b. Headline Fungicide Soybeans. Tech. Info. Bull. APN-08-01-088-0002. Research Triangle Park, NC.

BASF Corporation. 2009. Headline Fungicide Plant Health Research Summary. APN-09-01-088-0021. Research Triangle Park, NC.

Bluck, G. M., Lindsey, L. E., Dorrance, A. E., and Metzger, J. D. 2015. Soybean yield response to rhizobia inoculant, gypsum, manganese fertilizer, insecticide, and fungicide. Agron. J. 107:1757-1765.

Bradley, C. A., and Ames, K. A. 2010. Effect of foliar fungicides on corn with simulated hail damage. Plant Dis. 94:83-86.

Conley, S. P., Esker, P., and Gaska, J. 2010. Use of fungicides in hail-damaged crops. Pages 77-80 in: Proc. of the 2010 Wisconsin Crop Management Conference, Vol. 49. Univ. of Wisconsin, Madison.
Hartman, G. L., Rupe, J. C., Sikora, E. J., Domier, L. L., Steffey, K. L., and Davis, J. A. 2015. Compendium of Soybean Diseases and Pests, 5th ed. American Phytopathological Society, St. Paul, MN.

Hershman, D. E., Vincelli, P., and Kaiser, C. A. 2011. Foliar fungicide use in corn and soybeans. Coop. Ext. Publ. PPFS-MISC-05. University of Kentucky, Lexington.

Hicks, H. L., and Naeve, S. L. 2013. The soybean growers field guide for evaluating crop damage and replant options. Coop. Ext. Publ., University of Minnesota, St. Paul. http://www.extension.umn.edu/agriculture/ soybean/planting/the-soybean-growers-field-guide-for-evaluating-cropdamage-and-replant-options

Hodgson, E., Sisson, A., Mueller, D., Jesse, L., Saalau-Rojas, E., and Duster, A. 2012. Field Crop Insects. Ext. and Outreach: CSI 0014. Iowa State University, Ames.

Klein, R. N., and Shapiro, C. A. 2011. Evaluating hail damage to soybean. Coop. Ext. Publ. EC128. Univ. of Nebraska-Lincoln.

Kyveryga, P. M., Blackmer, T. M., and Mueller, D. S. 2013. When do foliar pyraclostrobin fungicide applications produce profitable soybean yield responses? Plant Health Prog. doi:10.1094/PHP-2013-0928-01-RS.

Lee, C. D., and Zarnstorff, M. E. 2012. Soybean yield loss caused by node removal. Crop Manage. doi:10.1094/CM-2012-1030-02-RS.

Licht, M., and Barnet, K. 2009. Yield response of hail-damaged soybeans treated with fungicide in Sac City, IA. Soybean Res. CSI 1001. Iowa State University Corn and Soybean Initiative, Ames.

Mahoney, K. J., and Gillard, C. L. 2014. Plant health and yield of dry bean not affected by strobilurin fungicides under disease-free or simulated hail conditions. Can. J. Plant Sci. 94:1385-1389.

Mahoney, K. J., Vyn, R. J., and Gillard, C. L. 2015. The effect of pyraclostrobin on soybean plant health, yield, and profitability in Ontario. Can. J. Plant Sci. 95:285-292.

Mueller, D. S., Wise, K. A., Dufault, N. S., Bradley, C. A., and Chilvers, M. I. 2013. Fungicides for field crops. American Phytopathological Society, St. Paul. MN.

Nelson, K. A., Tindall, K. V., Wrather, J. A., Stevens, W. E., and Dudenhoeffer, C. J. 2016. Value of an insecticide added to a fungicide for soybean during drought. Crop Forage Turfgrass Manage. doi:10.2134/cftm2015.0195

NOAA. 2006. Climate of Iowa. Central Region Headquarters, Nat. Climatic Data Center, Nat. Oceanic and Atmospheric Admin. (NOAA), Kansas City, MO. http://www.crh.noaa.gov/images/dvn/downloads/ Clim IA 01.pdf

Pedersen, P. 2009. Soybean Growth and Development. Ext. and Outreach Publ. PM 1945. Iowa State University, Ames.

Plastina, A., Johanns, A., and Weets, S. 2015. 2015 Iowa Farm Custom Rate Survey. Ag Decision Maker File A3-10. Iowa State University, Ames. http://www.extension.iastate.edu/agdm/crops/pdf/a3-10.pdf

Sisson, A. J., Kandel, Y. R., Robertson, A. E., Hart, C. E., Asmus, A., Wiggs, S. N., and Mueller, D. S. 2016. Effect of foliar fungicides on haildamaged corn. Plant Health Prog. 17:6-12. doi:10.1094/PHP-RS-150046.

Swoboda, C., and Pederson, P. 2009. Effect of fungicide on soybean growth and yield. Agron. J. 101:352-356.

USDA AMS (United States Department of Agriculture-Agricultural Marketing Service). 2015. Interior Iowa daily grain prices. USDA Market News, Des Moines, IA. http://search.ams.usda.gov/mndms/2015/08/ NW GR11020150806.TXT

USDA NASS (United States Department of Agriculture-National Agricultural Statistics Service). Quick Stats 2.0. USDA-NASS, Washington, DC. http://www.nass.usda.gov/Quick Stats/index.php. 